НАСОНОВА Людмила Ивановна - доктор философских наук, профессор кафедры гуманитарных и социально-экономических дисциплин Московской академии Следственного комитета РФ (125080, Россия, г. Москва, ул. Врубеля, 12; lynх.nasonova@yandex.ru)

ЛАЗЕБНЫЙ Леонид Иванович - доктор философских наук, профессор кафедры социологии Российского государственного социального университета (129226, Россия, г. Москва, ул. Вильгельма Пика, 4, стр. 1)

\title{
АСПЕКТЫ РОССИЙСКОЙ ИДЕНТИЧНОСТИ: ОПЫТ ПОСТАНОВКИ ПРОБЛЕМЫ
}

Аннотация. В статье рассматривается определение современной российской идентичности как реальная проблема российского общества, рефлексируемая в общественном сознании. Российская идентичность, с точки зрения авторов, имеет множество аспектов, среди которых можно выделить ряд наиболее актуальных, требующих социально-философского и конкретно-научного анализа.

Ключевые слова: российская идентичность, аспекты российской идентичности

И дентичность и как феномен, и как категория, и как инициация проблематики, поначалу носившая психологический характер, приобретает новую ценностную определенность в новых социально-исторических условиях в результате глобализации, которая носит не только объективный, но и необходимый характер, определяемый качественными изменениями социальных и экономических структур. Процессы социальной атомизации и диффузии начинают все более захватывать и разрушать традиционные общества, создавая социальные образования маргинального типа, в т.ч. в развитых современных государствах. Этот процесс, в свою очередь, требует осмысления и сопоставления с тенденциями существования и развития сложившихся цивилизаций, культурная самоопределенность которых требует переоценки и подтверждения собственной идентичности. В то же время гуманистическим направлением глобализации является развитие диалога между культурами. Процессы, связанные с глобализацией, выступают фактором интенсификации межкультурных контактов, сопровождаются поиском новых форм общения на основе взаимоуважения, толерантности, сохранения традиционных ценностей и приобщения к современным достижениям мировой культуры, в т.ч. для совместного решения глобальных проблем современности [Вопрос национальной... 2014: 5].

Проблема российской идентичности, связанная с глубинным пониманием ее индивидуальной сущности и самобытности, представляется вполне адекватной современному состоянию социальных процессов любого уровня и несомненно требующей четкой определенности направлений поиска ее решения, осознания своего цивилизационного пути и стратегической необходимости глобалистских интенций для обозначения собственной идентичности российского общества. Иными словами, российская идентификация - это процесс встраивания России в глобальный цивилизационный процесс в качестве ее самодостаточного, суверенного участника.

В течение последнего столетия этническая определенность вообще утрачивает актуальность и смысл, сохранив интенсивность лишь в развивающихся странах, решающих национально-территориальные проблемы, и сменяется определенностью геополитической: в ХІХ столетии появляются Североамериканские Соединенные Штаты, в XX столетии - Советский Союз и Соединенное Королевство. В этом глобальном процессе превращения этнического онтоса в геополитический выделяются два направления и, соответственно, две задачи: 
первая - установление глобального доминирования, вторая - сохранение собственной субъектности теми обществами, которые хотят обеспечить себе статус равноправного участника глобальной гонки доминирования. При этом эти участники в основном представляют собой полиэтничные образования, и в этом качестве они могут претендовать на успех. В этом плане задачами России являются, во-первых, сохранение ее целостности как субъекта социальных отношений на глобальном уровне, и во-вторых, совершенствование цивилизационного своеобразия - и для целей демаркации, и для развития внутреннего потенциала.

В процессе идентификации, с нашей точки зрения, должен реализоваться ряд ее аспектов, среди которых необходимо выделить конкретно-исторический, политический, геополитический, экономический, социокультурный, религиозный (сакральный), символический, информационный аспекты. Конечно, этот список не исчерпывает всех возможных аспектов идентификации и может быть дополнен. Так, в предшествующем столетии общество, сложившееся в границах нашей страны, идентифицировалось как советское, причем во всех указанных аспектах. В конкретно-историческом аспекте оно идентифицировалось как общество на этапе, следующем за капиталистическим (индустриальным) обществом, т.е. как общество социалистическое. В политическом аспекте общество идентифицировалось именно как советское: формально - демократическое, на деле - авторитарнобюрократическое.

В геополитическом отношении общество представляло собой обширнейший евразийский конгломерат разнородных в цивилизационном и этническом плане социальных образований; геополитическое единство обеспечивалось военно-политическим диктатом наиболее крупной по территории и народонаселению нации, возможным в условиях, к которым можно отнести, во-первых, цивилизационную отсталость азиатских народов и, во-вторых, отсутствие суверенитета европейских нерусских народов, входивших в состав советской державы (как столетиями ранее - в состав российской монархической державы).

В экономическом отношении советское общество идентифицировалось как в целом индустриальная система нерыночного типа с централизованным управлением. В социокультурном аспекте советское общество идентифицировалось как в целом прогрессистское общество, основанное на просветительской идеологии, притом содержащее на различных уровнях разнородные ментальные образования, отражающие специфику цивилизационного развития регионов; важнейшим связующим социокультурным компонентом выступал русский язык как государственный и как язык межнационального общения. В религиозном отношении советская идентичность характеризовалась государственным сакрализованным атеизмом (при декларированной свободе совести). На деле это сочеталось с фрагментированными ментально-религиозными образованиями самого различного характера - от мировых религий и их различных толков до родоплеменного язычества, причем для приличия все эти образования толковались как фольклор или преодолеваемые пережитки прошлого, тем более что они функционировали на обыденном уровне при государственном контроле над конфессиональными иерархиями. В символическом плане господствовала искусственная этнически и культурно нейтральная интернационально-пролетарская символика. Информационный аспект идентификации выражался в жестком тоталитарном диктате государственной идеологии при декларированной свободе слова и государственной поддержке лояльных направлений литературы и искусства (социалистический реализм, национальная прогрессистско-просветительская классика). 
Кризис советской идентичности в 1990-е гг. практически по всем ее направлениям возродил общественный интерес к проблеме русской идентичности, в значительной мере нивелированной идеологией этнически безликого интернационализма. Интерес этот выразился тем более ярко на фоне поиска или восстановления национальной идентичности и формирования суверенитета национальных республик, вышедших из состава советской федерации. В литературе этот процесс отразился как поиск новой «русской идеи», а также характера русского менталитета в новых исторических обстоятельствах [Историогенез и современное... 2015]. Разумеется, это было чисто интеллигентской затеей, эпизодически поддерживаемой некоторыми новоиспеченными политическими партиями и движениями при нейтральной позиции государственных систем, ведающих информационно-идеологическими процессами. Естественно, эта затея была истолкована как агрессивно-шовинистическая со стороны некоторых бывших советских республик, также осуществлявших поиск идейно-культурной национальной идентичности при одновременной лихорадочной культурно-идеологической (религиозной, информационной, символической) эмансипации. Заметим, что в идеологической системе огромной интернациональной советской империи понятие нации мыслилось как идейно враждебное, противопоставляющее национальное интернациональному. Не случайно самоназвание этой империи, даже у ее исторических истоков, уже утратило всякие следы этнонима «русский». Русской империи не было, была Российская, в XX столетии потерявшая смысл этнической определенности в контексте революционных преобразований и реальных глобалистских претензий. Излишне напоминать, что проект «русской идеи» в самом начале XXI в. был обречен в силу сущностной невыполнимости: новая Россия столь же многообразна в цивилизационном и этническом отношении, как и советская страна, и царская Россия. К этому добавим, что неявно мыслимое ментальное доминирование русской идеи в новой демократической России невозможно в условиях развития глобальных информационных систем. Интерес к русской идее окончательно угасает к исходу нулевых годов и совершенно закономерно при передышке, вызванной критическими внутри- и внешнеполитическими обстоятельствами, переходит в поиск новой - российской - идентичности. Само слово «русский» практически исчезает как этноним и становится в полной мере «прилагательным» К языковой сфере и литературно-художественному творчеству (по преимуществу прошлых эпох). Наше общество позиционируется как «российское», что напоминает нам «новую историческую общность - советский народ» брежневского периода. Отметим, однако, что конструкт «российское» оказался вполне приемлемым и культурно продуктивным для современного общества, поскольку представлял альтернативу как «советскому», так и «русскому». Семантика «российского» оказалась политически и культурно нейтральной, соотносимой с культурными кодами многих народов современной России и не содержащей неявную коннотацию доминирования «русского». Этот сдвиг в идеологически-культурном плане потребовал его продолжения и реального наполнения. Таким способом строится проблемное поле российской идентификации во всех ее существенных и необходимых аспектах.

Основные проблемы российской идентификации связаны, на наш взгляд, с конкретно-историческим аспектом. Если в советское время страна вполне определенно идентифицировалась с так называемым коммунистическим обществом как исторической формацией, то сейчас российское общественное сознание должно, во-первых, избрать для идентификации определенный формационный или цивилизационный тип и, во-вторых, указать мыслимое место 
России в общемировом развитии человечества. Нужно отметить, что данный аспект явно не находится в фокусе процесса идентификации. Видимо, сама постановка этой проблемы считается старомодной и не представляющей интереса для исследования и обсуждения. Однако необходимо отвечать на вызовы времени. Все чаще в социологических исследованиях просматривается ранжирование стран в мире, настоятельно требующее идентификации нашей страны в этом аспекте.

Политический аспект идентификации прежде всего подразумевает статус России как великой державы на мировой арене и как государства, во внутренней политике реализующего принципы демократии. Это направление прорабатывается достаточно успешно, например в области строительства многопартийной политической системы и развития институтов гражданского общества. Правда, возникают вопросы, связанные с ослаблением внимания к такому конструкту, как «правовое государство», и вообще к потребностям правового регулирования самых разнообразных сфер общественной жизни, ранее выпадавших из сферы интересов как государства, так и общественного мнения. В условиях утверждения новой государственности политическая идентичность оказывается значимым фактором государственной состоятельности; «в странах, решающих задачи социальной и политической модернизации, она активно используется как инструмент реализации государственной стратегии развития, a ее приоритеты и инструментарий становятся важнейшими индикаторами, позволяющими оценить характер политического режима» [Семененко и др. 2017: 58].

Геополитическая идентификация достаточно явственна: Россия - евразийская держава. Взаимное переплетение культур народов России создало между народами Евразии позитивную этническую конгениальность, чувство внутренней симпатии и тяготения, выработало общую систему ценностных ориентаций, мироощущения и способов мышления. Все это ведет к идее поликультурной, полиэтнической сообщности на основе двойной и не взаимоисключающей идентичности (культурно-этнической и государственно-гражданской) [Идентичность: личность... 2017].

«Осознание своей принадлежности к многонародному целому должно включать в себя вместе с тем и осознание своей принадлежности к определенному народу, составляющему части многонародного целого» [Трубецкой 1995: 111]. Поскольку евразийская идентичность России зачастую обосновывается на уровне ментальных ценностных образований, можно считать правомерной постановку проблем синтеза не только западноевропейских и исконно российских ценностей, но и синтеза российских ценностей с теми ценностями, которые сложились в недрах восточных культур, маркируемых конфессиональной принадлежностью, например исламской или буддийской, а также с ценностями и особенностями менталитета народов, населяющих сибирские просторы, составляющими особые традиции, не сводимые к культурным системам мировых или развитых национальных религий [Историогенез и современное... 2015]. Видимо, эта проблематика еще ожидает своей разработки. Необходимо заметить также, что геополитическая идентификация весьма многоаспектна и не исчерпывается культурно-ментальными или физико-географическими факторами. Евразийское направление идентификации должно быть подтверждено исследованиями объективистского характера в области государственной и социальной политики, в области экономики, экологии и демографии; к тому же евразийский статус нуждается в постоянном подтверждении и укреплении из-за преобладания азиатской территории (богатой природными ресурсами) над европейской и из-за малонаселенности Сибири. 
Экономическая идентификация представляется недостаточно определенной. Пусть термины «капитализм» или «социализм» являются устаревшими, но экономический тип и экономические приоритеты необходимо установить или хотя бы декларировать. Ведь имеющее место сочетание государственного планирования и частнопредпринимательской активности (о свободной конкуренции и речи нет) часто приобретает отчетливые формы экономического отчуждения в виде разросшейся системной коррупции. На повестке дня стоит выбор средств борьбы с ней, и в этом процессе все отчетливее проступают интенции плановой экономики. Все эти обстоятельства затрудняют четкую идентификацию в экономическом аспекте. Ясно одно: основные экономические категории и ценности требуют переосмысления [Новикова 2008: 19].

Социокультурная идентификация требует решения ряда проблем: прежде всего, это коренное улучшение качества жизни и доступность для всего населения комплекса современных социальных благ, основанных на новейших научно-технических достижениях, а также его овладение всеми продуктами современной цивилизации, которые обеспечат человеку возможность свободного выбора, перестройки и реализации профессиональной деятельности, что должно обеспечить высокую социальную мобильность.

Религиозный аспект идентификации достаточно проработан: Россия - страна свободы совести, веротерпимости и уважения к духовным ценностям любой (прежде всего, традиционной) конфессии, имеющим позитивное гуманистическое и моральное содержание. Это особенно явственно воплощается в развитии религиозных институтов и в храмовом строительстве. Доминирование православия на государственном уровне очевидно; трудно сказать, является ли это обстоятельство позитивным, проблематичным или нейтральным: в любом случае имеет место широкая проблемная область.

Символический аспект российской идентификации, несмотря на его кажущуюся второстепенность, представляется нам весьма важным: «стремительные изменения обращают человека к понятным, осязаемым формам репрезентации идентичности в символическом публичном пространстве и в практиках повседневности» [Семененко и др. 2017: 59]. Данный аспект требует еще очень большой работы по выявлению и адекватному оформлению всех культурных смыслов, образующих семантическое поле термина «российская идентичность». Следует заметить, что в этой сфере до сих пор царствует эклектика. Недостаточная культурно-историческая и экономическая идентифицированность препятствует внятному представлению образа настоящего и будущего России и, как следствие, порождает интерес к прошлому и его идеализацию. Причем ценность славного прошлого выражается в эклектичном смешении наглядных образов эпох и их идейных доминант. Очень удобная идеологема патриотизма не находит адекватного, внятного и компактного символического выражения (такого, как советские серп и молот, украинский трезубец, ирландская арфа, израильский семисвечник или французский фригийский колпак) [Косач 2014: 88]. Заявлена интерпретация двуглавого орла как символа евразийской державы, однако такая интерпретация вызывает сомнения. Во-первых, двуглавый орел является гербом не только России, но и ряда балканских государств, где он исторически связан с византийской державой, так же как и российский символ, в силу чего специфичность последнего существенно ослабляется, а статус великой державы снижается до уровня статуса держав второстепенных. Во-вторых, уж слишком этот символ обращен в монархическое прошлое; причем психологически стремление гордиться славным прошлым в некоторой степени явно отягощается комплексом вины за утраченное в революционных событиях прошлого века национальное достоя- 
ние, к которому можно отнести и утраченные материальные ценности, и негативные демографические процессы (сокращение населения вследствие войн и неквалифицированного управления), и неэффективную перестройку социальной системы (эмиграция, массовые социальные репрессии), и процессы духовно-культурной деградации. Цветовая символика российского триколора совершенно невнятна: сочетание его цветов настолько распространено в мире и представлено на государственных флагах, что требует его четкой интерпретации в соотношении с государственными или историческими ценностями и трансляции этой интерпретации в массовое сознание. Для сравнения, советская символика (цвет знамени, символы, рисунок герба) удачно разрабатывалась в полном соответствии с принятыми официальными государственно-идеологическими доминантами и успешно внедрялась в общественное сознание ударными темпами (разумеется, на фоне исторического нигилизма). Сейчас решение задач символической идентификации осложняется явственно ощутимым стремлением к ретроспекции, к возрождению символов славного прошлого, в качестве которых выступают памятники-символы (историко-географические или архитектурные объекты) [Перхавко 2017]. Однако при темпах современного социального развития для идентификации не менее важными являются символы настоящего, а может быть, и символы вневременные, долгоживущие, опирающиеся на историческую память, проходящие сквозь радикальные трансформации, стабильно отражающие цивилизационные особенности и в то же время устремленные в будущее [Зарубина 2017: 55].

Идентификация в информационном аспекте связана прежде всего с решением задач свободного доступа граждан к информации, овладения всем населением современными техническими средствами информации, а также с воспитанием умения осуществлять поиск необходимой, обоснованной и достоверной информации, с формированием знаний о методах этого поиска, с совершенствованием образовательных систем. В этих направлениях осуществляется активная и эффективная деятельность, однако, видимо, трудно пока еще определенно ответить на вопрос, является ли российское общество информационным. Российская идентификация, как и любая современная идентификация, невозможна без ее информационного аспекта. Современное общество - информационное общество. Эта реалия предопределяет необходимость действий, отвечающих вызовам времени.

Рассмотренные аспекты идентификации не исчерпывают всех направлений процесса ее исследования. Отметим, однако, что должно быть продуктивным выделение и тщательный анализ важнейших из них как для определения места России в мировом процессе развития, так и для утверждения собственного достоинства в самосознании российского общества. Эта теоретическая работа должна иметь своим результатом выработку адекватных, практически осуществимых и эффективных рекомендаций по решению неотложных современных задач, прежде всего политического, социально-экономического и культурноинформационного характера.

\section{Список литературы}

Вопрос национальной идентичности в контексте глобализации (отв. ред. А.Н. Чумаков). 2014. М.: Проспект. 141 с.

Зарубина Н.Н. 2017. Историческая память как источник знаний о цивилизационной специфике России. - Общественные науки и современность. № 2. C. 52-62.

Идентичность: личность, общество, политика (отв. ред. И.С. Семененко). 2017. М.: Весь Мир. 987 с. 
Историогенез и современное состояние российского менталитета (отв. ред. В.А. Кольцова, Е.В. Харитонова). 2015. М.: Изд-во Института психологии РАН. $480 \mathrm{c}$.

Косач Г. 2014. Война символов. - Свободная мысль. № 5. С. 87-96.

Новикова Е.Ю. 2008. Ценности и экономическая деятельность. - Вестник Российского экономического университета им. Г.В. Плеханова. № 4(22). С. 14-21.

Перхавко В. 2017. Общественное мнение и законодательство об историкокультурном наследии (20 - начало 21 вв.). - Российская история. № 3. С. 149162.

Семененко И.С., Лапкин В.В., Бардин А.Л., Пантин В.И. 2017. Между государством и нацией: дилеммы политики идентичности на постсоветском пространстве. - Полис. Политические исследования. № 5. С. 54-78.

Трубецкой Н.С. 1995. История. Культура. Язык. М.: Прогресс. 797 с.

NASONOVA Lyudmila Ivanovna, Dr.Sci. (Philos.), Professor of the Chair of Humanities and Socio-Economic Disciplines, Moscow Academy of the Investigative Committee of the Russian Federation (12 Vrubelya St, Moscow, Russia, 125080; lynx.nasonova@yandex.ru)

LAZEBNY Leonid Ivanovich, Dr.Sci. (Philos.), Professor of the Chair of Sociology, Russian State Social University (bld. 1, 4 Wil'gel'ma Picka St, Moscow, Russia, 129226)

\section{ASPECTS OF RUSSIAN IDENTITY: AN EXPERIENCE OF THE PROBLEM STATEMENT}

Abstract. The article discusses the definition of modern Russian identity as a real problem of Russian society, reflected in public consciousness. The Russian identity, from the point of view of the authors, has many aspects, among which a number of the most relevant, requiring a socio-philosophical and concrete scientific analysis.

Keywords: Russian identity, aspects of Russian identity 